\title{
水素燃焼機関における作動流体の熱物性値と壁面熱伝達の関係*
}

\author{
首藤 登志夫*1, 岡 紘 子*2

\section{Thermophysical Properties of Working Fluid and Heat Transfer in a Hydrogen Combustion Engine}

\author{
Toshio SHUDO*3 and Hiroko OKA \\ ${ }^{* 3}$ Department of Mechanical Engineering, Kitami Institute of Technology, \\ 165 Koencho, Kitami-shi, Hokkaido, 090-8507 Japan
}

\begin{abstract}
A larger burning velocity and a shorter quenching distance for hydrogen as compared with hydrocarbons bring a higher degree of constant volume and a larger cooling loss from burning gas to the combustion chamber wall in internal combustion engines. Because of the large cooling loss, the reduction of the cooling loss are crucial for improving the thermal efficiency in hydrogen combustion engines. Empirical correlation for total heat transfer from burning gas to the combustion chamber walls are often used to calculate the cooling loss. However, previous research by the authors has shown that the widely used heat transfer correlation reported by Woschni cannot be properly applied to the hydrogen combustion. For this background, this research analyzes the relationship between characteristics of thermophysical properties of working fluid and heat transfer to the wall in a hydrogen-fueled spark-ignition engine.
\end{abstract}

Key Words: Internal Combustion Engine, Hydrogen, Heat Transfer, Combustion, Thermophysical Property, Working Fluid

\section{1. 緒言}

水素を燃料に用いた内燃機関においては，作動流体 から燃焼室壁面への熱伝達による冷却損失が熱効率に 大きな影響を及ぼしていることが特徵的である(1)-(3).

一方, 内燃機関の冷却損失を見積もるために，作動流 体と燃焼室壁面との間の総括的な熱伝達率を表す実験 式がこれまでにいくつか提案されている，しかし，そ れらの式は炭化水素燃焼の実験結果に基づくものであ り，燃焼および冷却損失の特性が炭化水素と大きく異 なる水素の燃焼に対しての適用は妥当ではないことが 分かっている(4)-(5).

水素燃焼機関では，大きな燃焼速度のために作動流 体の比熱比変化が速いことから，炭化水素を燃料に用 いた通常の機関に比べて熱発生率算出における比熱比 変化率項の寄与度が高く，この項を省略すべきではな いことが明らかになっている(6).このように，水素燃 焼機関では燃焼過程における作動流体の熱物性値の特 性が炭化水素燃焼とは異なっており,このことが従来 の壁面熱伝達式を適用できない原因となっている可能 性がある。

* 原稿受付 2004 年 4 月 23 日.

*1 正員, 北見工業大学機械システム工学科(⓪90-8507 北見 市公園町 165)。

*2 元：武蔵工業大学大学院工学研究科.

E-mail : shudoto@mail.kitami-it.ac.jp
そこで，本研究では水素燃焼機関の燃焼過程におけ る作動流体の熱物性值の挙動について，メタンを燃料 とする場合と比較しながら解析するとともに，壁面熱 伝達との関わりについて検討を行った。

\section{2. 記 号}

$\phi$ : 当量比

$n$ : エンジン回転速度 $(\mathrm{rpm})$

$\eta_{\mathrm{v}}$ : 体積効率 $(\%)$

$\theta$ : クランク角度 $\left({ }^{\circ} \mathrm{CA}\right)$

$\theta_{\text {ig }}$ : 点火時期 $\left({ }^{\circ} \mathrm{CA} \mathrm{BTDC}\right)$

$\eta_{\mathrm{u}}$ : 燃焼効率

$Q_{\text {fuel }}: 1$ サイクルに供給した燃料の発熱量 $(\mathrm{J})$

$Q: 1$ サイクルの見かけの熱発生量 $(\mathrm{J})$

$\mathrm{d} Q / \mathrm{d} \theta$ : 見かけの熱発生率 $\left(\mathrm{J} /{ }^{\circ} \mathrm{CA}\right)$

$Q_{\mathrm{B}}: 1$ サイクルの実熱発生量 $(\mathrm{J})$

$\mathrm{d} Q_{\mathrm{B}} / \mathrm{d} \theta:$ 実熱発生率 $\left(\mathrm{J} /{ }^{\circ} \mathrm{CA}\right)$

$Q_{\mathrm{c}}$ : 1サイクルの冷却損失量 $(\mathrm{J})$

$\mathrm{d} Q_{\mathrm{C}} / \mathrm{d} \theta$ : 冷却率 $\left(\mathrm{J} /{ }^{\circ} \mathrm{CA}\right)$

$\phi_{\mathrm{w}}$ : 冷却損失割合, $\phi_{\mathrm{w}}=Q_{\mathrm{C}} / Q_{\mathrm{B}}$

$\gamma:$ 比熱比

$T_{\mathrm{w}}$ : 燃焼室壁面温度 $(\mathrm{K})$

$T_{\mathrm{g}}$ : 燃焼空内平均温度 $(\mathrm{K})$

$P$ : 燃焼室内圧力 $(\mathrm{Pa})$

$V$ : 燃焼室内容積 $\left(\mathrm{m}^{3}\right)$ 


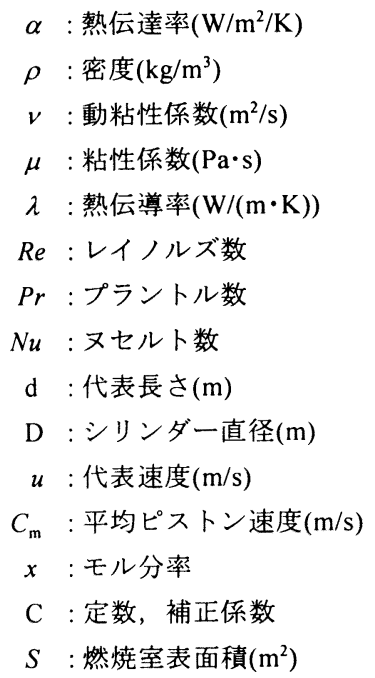

\section{3. 実験装置および実験方法}

本研究に使用した機関は，4気筒4サイクル自動車用 火花点火ガソリン機関 (ボア $85 \mathrm{~mm}$, ストローク $88 \mathrm{~mm}$, 圧縮比 8.5)に気体然料供給系を追加したものである. 実験においては, 燃料の水素あるいはメタンを吸気管 内に連続供給し，予混合燃焼を行った。図1のように シリンダーヘッドに取り付けたピエゾ式圧力変換器 (AVL GM12D)により燃焼室内圧力を計測し，各実験 条件について50サイクル分の圧力データを平均した後 に，見かけの熱発生率等の解析に使用した。 また，シ リンダーヘッドに取り付けた高応答薄膜型熱電対 (Metherm TCS103E，クロメル・コンスタンタン型)に より燃焼室壁表面の瞬時温度の計測を行った。なお, 全ての実験条件において, 混合気の当量比を $\phi=1.0$, 機 関回転速度を $\mathrm{n}=1500 \mathrm{rpm}$, 燃料ガスを含めた体積効率 を $\eta_{\mathrm{v}}=35 \%$ に設定した。

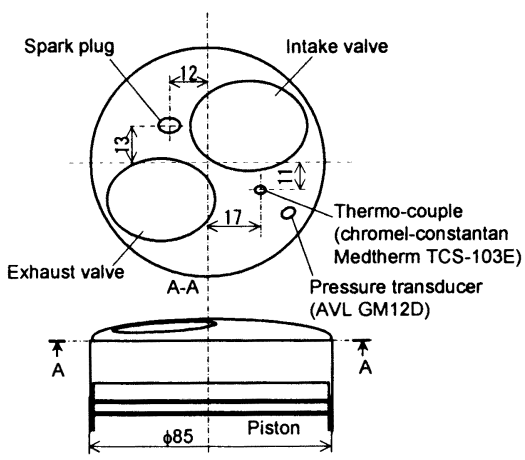

Fig.l Combustion chamber of tested engine

\section{4. 解析方法}

冷却率 $\mathrm{d} Q_{\mathrm{C}} / \mathrm{d} \theta$ は, 燃焼室内圧力の解析から求めた見 かけの熱発生率 $\mathrm{d} Q / \mathrm{d} \theta$ と実熱発生率 $\mathrm{d} Q_{\mathrm{B}} / \mathrm{d} \theta$ により次の ように表され,

$$
\mathrm{d} Q_{\mathrm{C}} / \mathrm{d} \theta=\mathrm{d} Q_{\mathrm{B}} / \mathrm{d} \theta-\mathrm{d} Q / \mathrm{d} \theta
$$

1サイクルの冷却損失熱量 $Q_{\mathrm{C}}$ は以下のようになる.

$$
Q_{\mathrm{C}}=Q_{\mathrm{B}}-Q
$$

また，実熱発生量 $Q_{\mathrm{B}}$ は1サイクルに供給された燃料が 持つ発熱量 $Q_{\text {fuel }}$ と燃焼効率 $\eta_{\mathrm{u}}$ の積に相当するため, 冷 却損失熱量 $Q_{\mathrm{c}}$ を次のように表すこともできる.

$$
Q_{\mathrm{C}}=\eta_{\mathrm{u}} Q_{\text {fuel }}-Q
$$

この冷却率 $\mathrm{d} Q_{\mathrm{C}} / \mathrm{d} \theta$ あるいは冷却損失熱量 $Q_{\mathrm{C}}$ を求めるこ とを目的として, 内燃機関のための壁面熱伝達式が古 くから報告されている。 それらの式によって導かれる 燃焼室壁面全体の平均熱伝達率 $\alpha$, ならびに作動流体

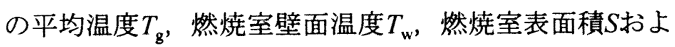
び機関回転速度 $n$ を用いて, 冷却率 $\mathrm{d} Q_{\mathrm{C}} / \mathrm{d} \theta$ が次式によ り求められる.

$$
\mathrm{d} Q_{\mathrm{C}} / \mathrm{d} \theta=\alpha S\left(T_{\mathrm{g}}-T_{\mathrm{w}}\right) /(6 n)
$$

本研究では, 作動流体の温度 $T_{\mathrm{g}}$ に燃焼室内圧力から熱 力学的に求めた燃焼室内平均温度を用い, 燃焼室壁面 の温度 $T_{\mathrm{w}}$ に熱電対による計測值を用いた．また，見か けの熱発生率 $\mathrm{d} Q / \mathrm{d} \theta$ 算出は次式により行った。

$$
\begin{aligned}
\mathrm{d} Q / \mathrm{d} \theta= & (V \mathrm{~d} P / \mathrm{d} \theta+\gamma P \mathrm{~d} V / \mathrm{d} \theta) /(\gamma-1) \\
& -P V /(\gamma-1)^{2} \mathrm{~d} \gamma / \mathrm{d} \theta
\end{aligned}
$$

この際, 見かけの熱発生率から求めた燃焼質量割合に より燃焼室内の作動流体の組成を導出して比熱比 $\gamma$ を 算出し, 得られた比熱比を用いて再び見かけの熱発生 率を求める計算を繰り返すことで見かけの熱発生率の 計算值を収束させた。この式の中で, 比熱比変化率 $\mathrm{d} \gamma / \mathrm{d} \theta$ の項は, 熱発生率算出の際にしばしば省略され ることもあが, 燃焼期間が短く燃焼過程での作動流体 の組成および温度の変化が速い水素燃焼においては, 見かけの熱発生率に対する比熱比変化率項の寄与度が $30 \%$ 程度に達することから ${ }^{(6)}$ ，この項を含めた計算を 行った。

式(5)により得られた見かけの熱発生率 $\mathrm{d} Q / \mathrm{d} \theta$ をク ンク角 $\theta$ で積分したものを見かけの熱発生量 $Q$ とした. 見かけの熱発生量により求めた質量燃焼割合から作動 流体の各成分のモル分率を算出した。 また，燃焼室内 の平均温度および圧力に基づいて作動流体各成分の熱 物性値を物性值表 ${ }^{(8)}$ から推定し，各成分のモル分率を 考慮して作動流体全体の熱物性值をクランク角毎に求 めた. 

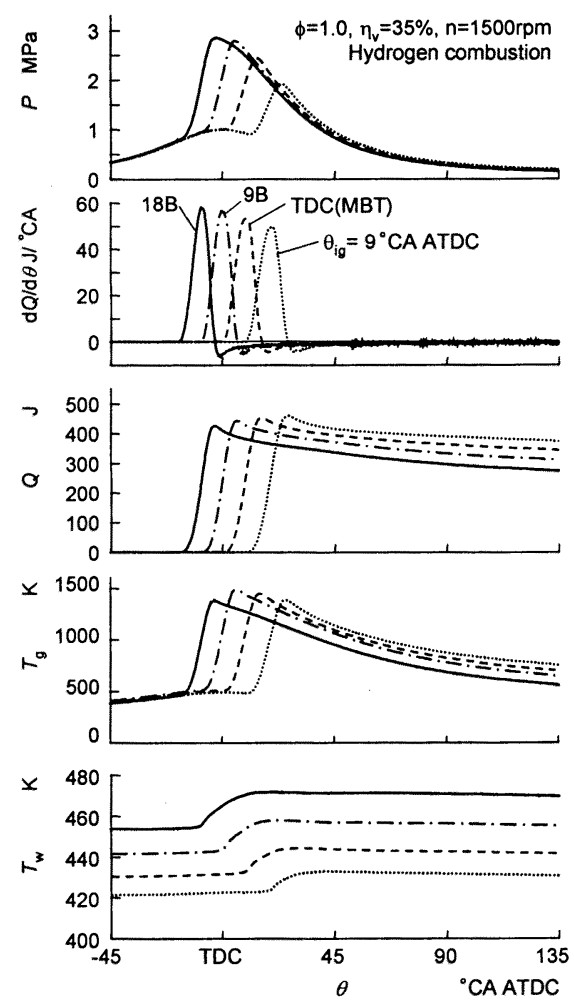

(a) Hydrogen combustion
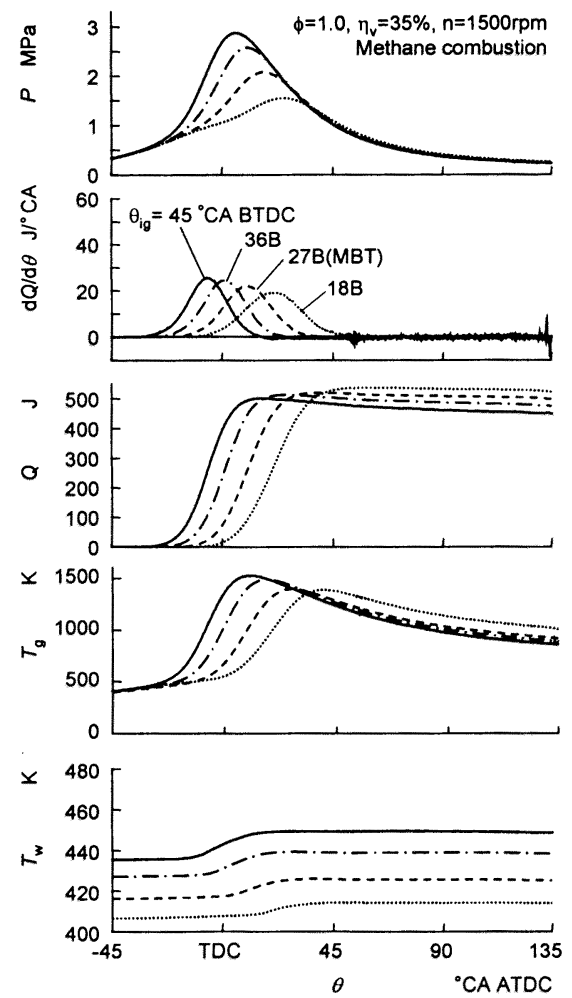

(b) Methane combustion

Fig.2 Hydrogen combustion and methane combustion for different ignition timings

\section{5. 結果および考察}

$5 \cdot 1$ 従来の壁面熱伝達式 内燃機関において作動流 体から燃焼室壁面への熱伝達を表現する実験式が古く から提案されているが, それらの多くは, ヌセルト数 $\mathrm{Nu}$, レイノルズ数 $R e$, プラントル数Prから成る円管内 乱流熱伝達に関する実験整理式を基にしている.

$$
N u=\mathrm{C} R e^{\mathrm{m}} \mathrm{Pr}^{\mathrm{n}}
$$

この円管内乱流熱伝達式に対して, 内燃機関では燃焼 過程においても作動流体のプラントル数Prの変化が十 分に小さいとして，次式のようにプラントル数Prを定 数として取り扱い，

$$
\mathrm{Nu}=\mathrm{C} R e^{\mathrm{m}}
$$

さらに，実験による近似等を経て導出された式が内燃 機関の壁面熱伝達を表す式として提案されている。そ れらの式の多くは，次のように燃焼室内圧力 $P$, 燃焼 室内平均温度 $T_{\mathrm{g}}$, シリンダ直径 $\mathrm{D}$, 平均ピストン速度 $C_{\mathrm{m}}$ 等の関数として, 燃焼室壁面全体の総括的な熱伝達 率 $\alpha$ 表す形を採っている.

$$
\alpha=f\left(P, T_{\mathrm{g}}, \mathrm{D}, C_{\mathrm{m}}\right)
$$

図2は，水素またはメタンの化学量論混合気の燃焼 において点火時期をパラメータとした実験結果である. メタンに比べて燃焼速度が大きい水素を用いた場合に は，燃焼期間が短く，燃焼過程における作動流体およ び燃焼室壁面の温度変化が急激であることが分かる。 また, 燃焼終了後に見かけの熱発生率が負になる領域 が大きく，水素燃焼では作動流体から燃焼室壁面への 熱伝達量がメタン燃焼に比べて大きい(1)ことが窥える. この実験結果に対して，内燃機関の研究開発において 広く使用されるWoschni式(7)を適用した計算結果が図3 である。図は，Woschni式による冷却損失熱量 $Q_{\mathrm{c}}$ と見 かけの熱発生量 $Q か ら$ 求めた実熱発生量波形であり， 供給燃料熱量 $Q_{\text {fue }}$ と燃焼効率 $\eta_{\mathrm{u}}$ から求めた1サイクルの 実熱発生量 $\eta_{\mathrm{u}} Q_{\text {fuel }}$ で割ることで無次元表示している. なお，燃焼効率は排気分析により算出した。ここで， Woschni式を水素燃焼に使用した場合には，冷却損失 が実際よりも小さく計算される(4)ことから，排気弁開 時期において以下の関係を満たすように計算値に補正 
係数Cを乗じた.

$$
Q+\mathrm{C} Q_{\mathrm{c}}=\eta_{\mathrm{u}} Q_{\text {fuel }}
$$

図より,メタン燃焼では計算值が実験值に滑らかに漸 近するのに対して, 水素燃焼では計算值が燃焼終了後 に実験值を上回るような条件もあり，Woschni式を用 いた冷却損失の計算が明らかに妥当ではないことが分 かる.
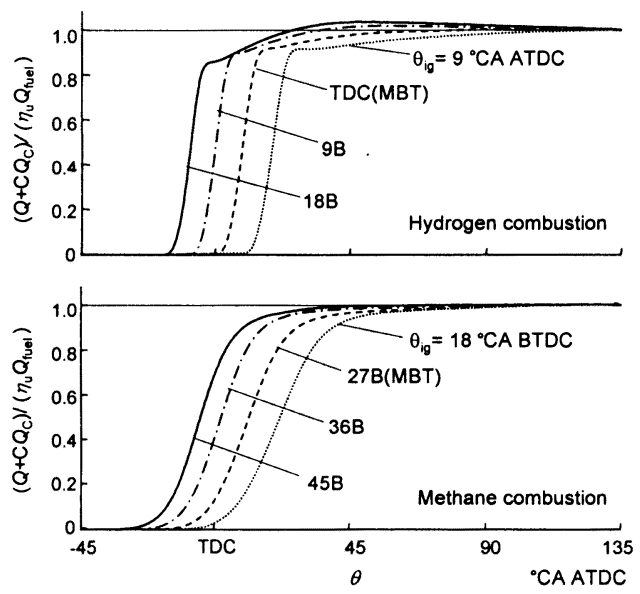

Fig. 3 Normalized cumulative real heat release by Woschni's equation with correcting coefficient

$5 \cdot 2$ 作動流体のプラントル数＼cjkstart前節の結果のように, 従来の壁面熱伝達式では水素燃焼機関に対して妥当な 計算結果が得られない。この原因の一つとして，従来 の式が適用対象とする炭化水素燃焼と比べて水素燃焼 での熱物性值の特性が異なることが考えられる.メタ ン燃焼に比べて燃焼期間が短い水素燃焼では，燃焼過 程における作動流体の組成および温度の変化が急激で あることから, 従来の式における熱物性值の取り扱い が適切ではない可能性がある．例えば，定数として扱 われている作動流体のプラントル数Prの特性が水素然 焼では炭化水素燃焼と異なることも考えられる. そこ で，水素燃焼機関の燃焼過程における作動流体のプラ ントル数の举動について検討を行った.

図4は，図2の最適点火時期での実験結果について, 作動流体の各成分のプラントル数Prならびにプラント ル数Prにモル分率 $x$ を掛けた值の燃焼過程での変化を示 したものである. 各成分のプラントル数は, 燃焼室内 の平均温度および圧力に基づいて物性值表 ${ }^{(8)}$ から推定 した. 燃焼期間が短い水素燃焼では各成分のプラント ル数の変化が急激であり, とくに $\mathrm{H}_{2} \mathrm{O}$ のプラントル数 の変化が大きいことが特徴的である.
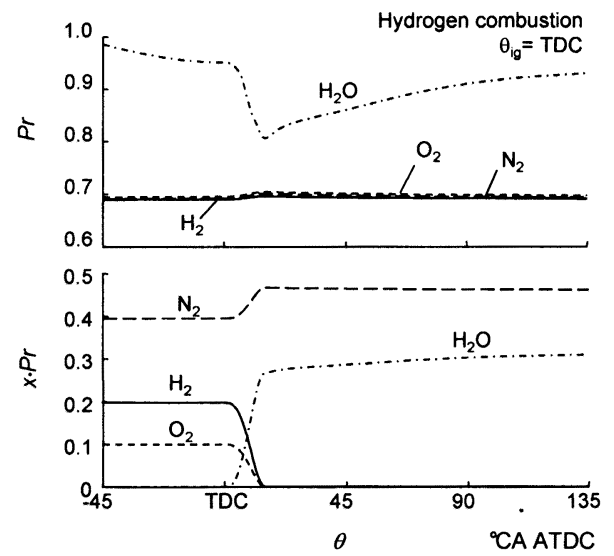

(a) Hydrogen combustion

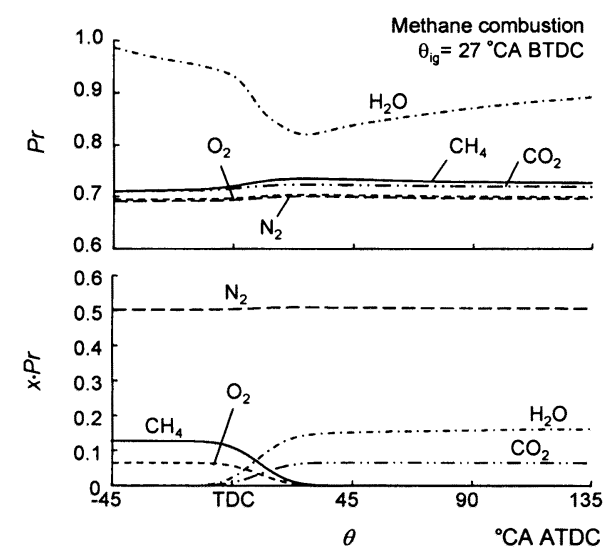

(b) Methane combustion

Fig.4 Prandtl number of each species during combustion process

図5は，図2の各点火時期条件の実験結果について作 動流体のプラントル数を示したものであり，図6は最 適点火時期条件において水素然焼とメタン燃焼を比較 した結果である．何れの点火時期においても，水素燃 焼ではメタン燃焼に比べて燃焼過程でのプラントル数 の変化量が大きいことが図から分かる．しかし，気体 の円管内乱流熱伝達を表す以下のKaysらによる式等にお いてはプラントル数の指数として 0.5 程度の值が用いられて おり(9)-(10), この指数を考慮するとその変化量の影響は 小さく, $\mathrm{Pr}^{0.5}$ 変化は水素の化学量論燃焼過程におい ても3\%程度である。

$$
N u=0.022 \operatorname{Re}^{0.8} \operatorname{Pr}^{0.5} \quad(0.5<\operatorname{Pr} \leqq 1.0)
$$

以上より，水素燃焼機関の作動流体のプラントル数の 燃焼過程での変化は，炭化水素燃焼に比べて大きいが, 壁面熱伝達式におけるその奇与は小さく，水素然焼機 
関の壁面熱伝達を計算する際にもプラントル数を定数 として取り扱うことの影響は小さいと考えられる。

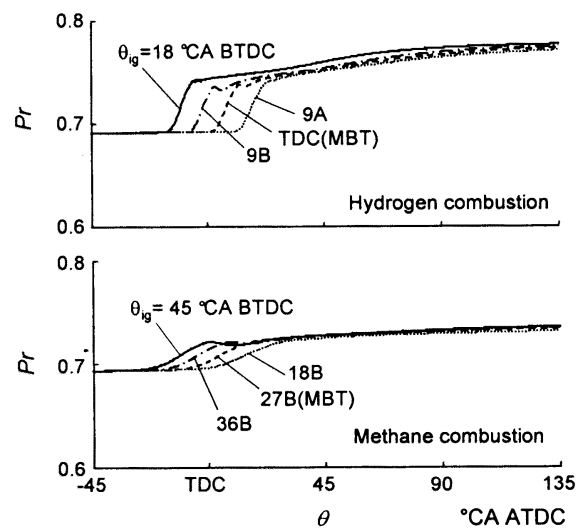

Fig.5 Prandtl number of working fluid during combustion process for different ignition timings

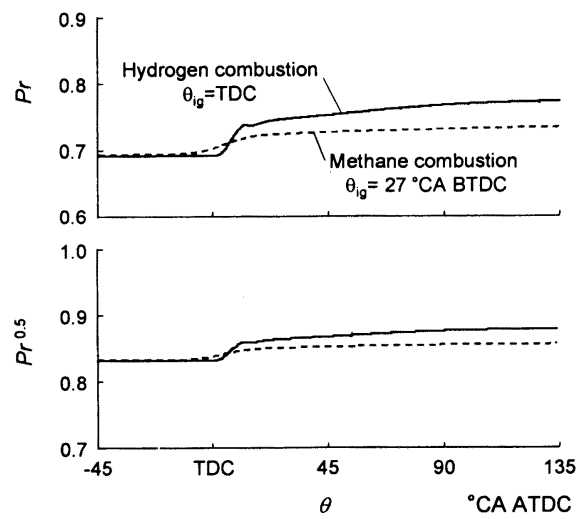

Fig.6 Changes in $\operatorname{Pr}$ and $\operatorname{Pr}^{0.5}$ of working fluid during combustion process

$5 \cdot 3$ 作動流体の熱伝導率 水素は気体の中でとりわけ 大きな熱伝導率を持つことから，水素然機関における作 動流体の熱伝導率の挙動は興味深い. 図7は, 図2の最適 点火時期条件での実験結果について, 物性值表 ${ }^{(8)}$ から推 定した作動流体の熱伝導率 とモル分率 $x$ を掛け合わせた值の燃焼過程における変化を 示している. 水素の大きな熱伝導率のために, メタン燃 焼と比較して水素燃焼の作動流体が燃焼前に特に大きな 熱伝導率を持つことが特徴である. しかし，作動流体か ら燃焼室壁面への熱伝達が主に生じる燃焼過程および燃 焼終了後における作動流体の熱伝導率には両者の間で極 端な差は見られないことが分かる。
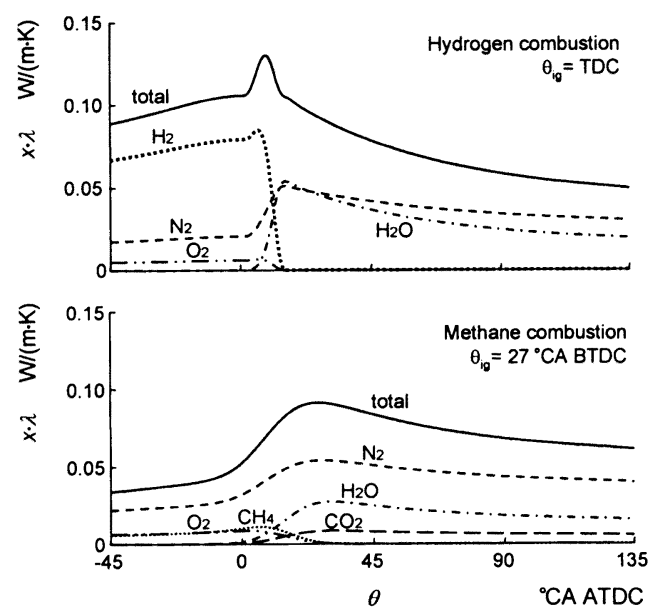

Fig.7 Thermal conductivity of each species during combustion process

$5 \cdot 4$ 円管内乱流熱伝達式による計算 ヌセルト数 $N u$ およびレイノルズ数Reは, 代表長さd, 熱伝導率 $\lambda$, 代 表速度 $u$, 動粘性係数によより以下のように表され，

$$
\begin{aligned}
& N u=\alpha \mathrm{d} / \lambda \\
& R e=u \mathrm{~d} / v
\end{aligned}
$$

これらを式(6)に代入すると熱伝達率 $\alpha か ゙$ 次のように表 せる.

$$
\alpha=\mathrm{Cd}^{\mathrm{m}-1} \lambda v^{-\mathrm{m}} u^{\mathrm{m}} \operatorname{Pr}^{\mathrm{n}}
$$

ここで，5・2節の結果に基づきプラントル数Prを定数 とし，円管内乱流熱伝達式におけるレイノルズ数 Reの 指数として一般的な值である $0.8 を \mathrm{~m} に$ 代入すると次式 のようになる.

$$
\alpha=\mathrm{Cd}^{-0.2} \lambda v^{-0.8} u^{0.8}
$$

また, 動粘性係数 $v$ は粘性係数 $\mu$ おび密度 $\rho$ により表 せるため熱伝達率 $\alpha$ を下のように表すことができる.

$$
\alpha=\mathrm{Cd}^{-0.2} \lambda \mu^{-0.8} \rho^{0.8} u^{0.8}
$$

内燃機関のための壁面熱伝達式の多くにおいては，代 表速度 $u$ として平均ピストン速度が用いられる．一般 に機関試験が行われる回転速度一定の条件では, 平均 ピストン速度は燃焼過程においても一定であり，また 代表長さdであるシリンダー直径も一定となることか ら，式(15)により算出される熱伝達率 $\alpha$ の燃焼過程での 変化は $\lambda \mu^{-0.8} \rho^{0.8}$ の変化に支配されることになる. 図8は， 図2の実験結果に対して, 作動流体の熱伝導率 $\lambda$, 密度 $\rho$ ，および粘性係数 $\mu$ おいてそれぞれ指数を考慮した もの，ならびに $\lambda \mu^{-0.8} \rho^{0.8}$ の值を示している. 図より， 水素燃焼における作動流体の $\lambda \mu^{-0.8} \rho^{0.8}$ の值は燃焼前に おいてメタン燃焼よりも大きく，燃焼の進行に伴って 
大きく減少する傾向を示すことが分かる，水素燃焼に おいて $\lambda \mu^{-0.8} \rho^{0.8}$ が燃焼前に大きな值をとることは水素

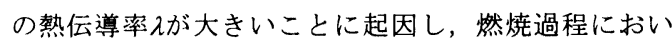
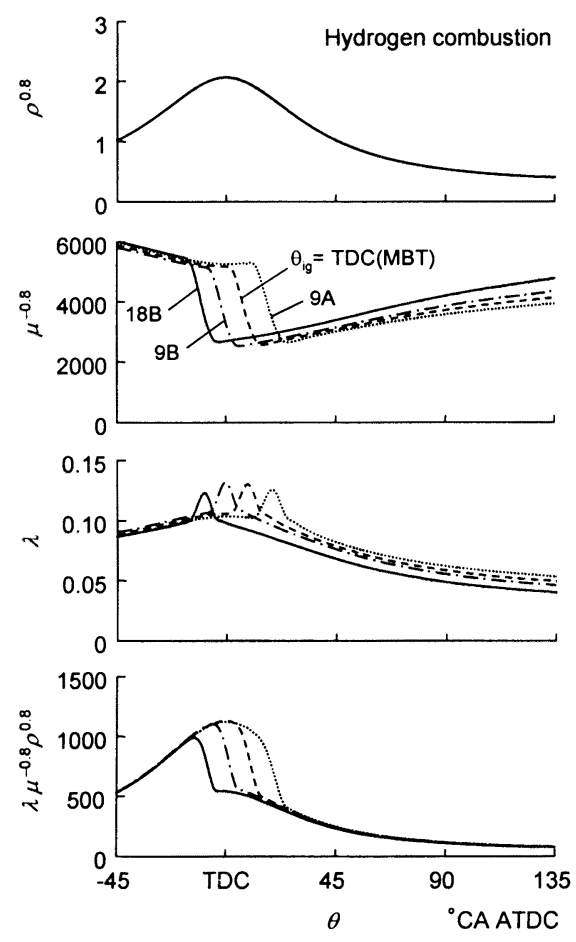

(a) Hydrogen combustion
て $\lambda \mu^{-0.8} \rho^{0.8}$ が急速に減少する傾向は燃焼に伴う作動流 体の急激な温度上昇のために粘性係数 $\mu$ が増加するこ とに起因するものと考えられる.
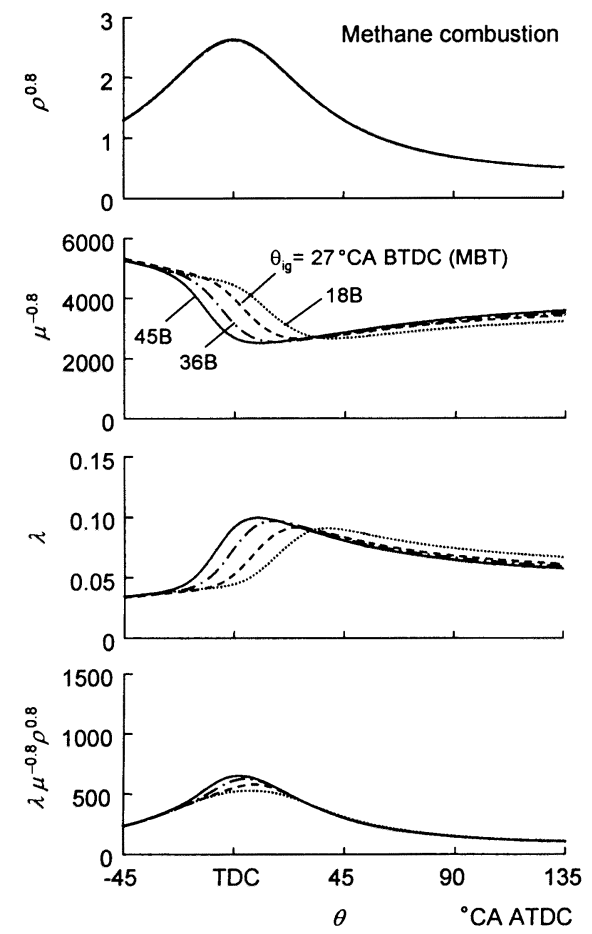

(b) Methane combustion

Fig.8 Changes in $\rho^{0.8}, \mu^{-0.8}, \lambda$ and $\lambda \mu^{-0.8} \rho^{0.8}$ during combustion process for different ignition timings
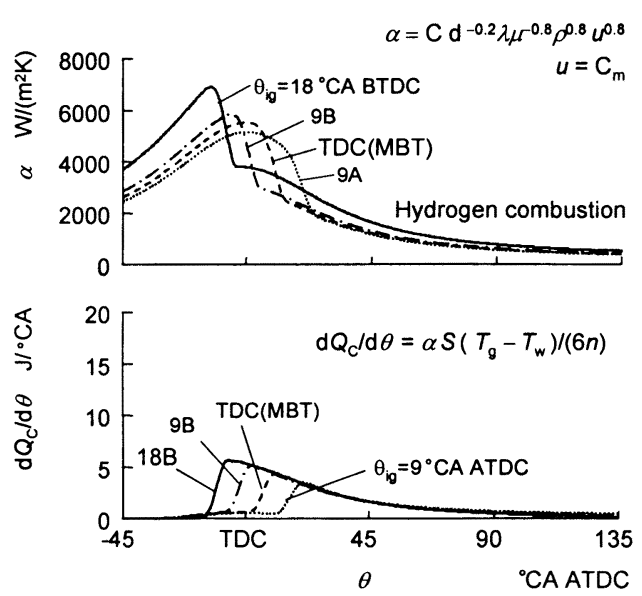

Fig.9 Heat transfer coefficient and rate of cooling calculated by the heat transfer equation for turbulent flow in circular tubes using mean piston speed
図9は, 水素燃焼の実験結果において, 式(15)から熱 伝達率 $\alpha$ を求め, 式(4)により冷却率 $\mathrm{d} Q_{\mathrm{C}} / \mathrm{d} \theta$ を算出した 結果である。代表速度 $u$ には平均ピストン速度 $\mathrm{C}_{\mathrm{m}}$ を用 い, 1サイクルあたりの冷却率の積分值 $Q_{\mathrm{C}}$ が式(3)によ る実験值と一致するように式(15)の定数Cを各点火時期 に対して決定した. 図より, 点火時期 $\theta_{\mathrm{ig}}$ の進角に伴っ て燃焼前の熱伝達率 $\alpha$ が増加する傾向が見られる。し かし実際には，燃焼開始前の作動流体の熱伝達特性は 点火時期の影響を殆ど受けないと考えられることから， 平均ピストン速度を代表速度として円管内乱流熱伝達 式により熱伝達率を算出したこの結果が妥当ではない ことが窥える。図10は，図9の最適点火時期の結果に ついて冷却損失波形を実験值と比較した結果である。 なお，実験值はWiebeの燃焼関数を用いて見かけの熱 発生量と燃焼効率から見積もった ${ }^{(6)}$. 図より, 平均ピ ストン速度を代表速度として円管内乱流熱伝達式によ り水素燃焼機関の壁面熱伝達を計算した場合, 燃焼過 
程での熱伝達量の増加を十分に表せていないことが分 かる.この原因として，燃焼過程においても変化しな い平均ピストン速度を代表速度とした場合には，水素 燃焼の急激な火炎伝播に伴う作動流体の対流による熱 伝達率の増加が表現できないことが考えられる，例え ば，Woschni式は燃焼に伴う流動の増加による影響を 近似する目的で機関運転時とモータリング時の燃焼室 内圧力の差を代表速度項の中に導入しているが(7), 図3 の結果から分かるように, その効果は水素然焼に対し て十分ではない.

以上, 水素燃焼機関において作動流体から燃焼室壁 面への熱伝達を計算する際には, 燃焼過程での対流の 増加に対応した適切な代表速度の取り扱いが課題であ る.

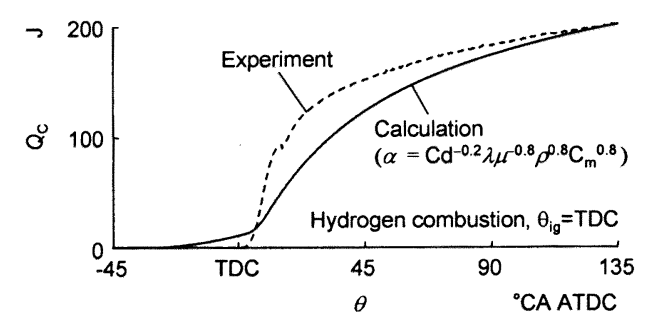

Fig.10 Cumulative cooling loss in hydrogen combustion calculated by the heat transfer equation for turbulent flow in circular tubes using mean piston speed

\section{6. 結 論}

（1） 水素燃焼機関の燃焼過程における作動流体のプ ラントル数の変化は炭化水素燃焼機関と比較して大き いが，熱伝達式におけるプラントル数の指数を考慮す るとその寄与は小さく，水素燃焼機関の燃焼室壁面熱 伝達率を算出する際にもプラントル数を定数として取 り扱うことの影響は小さい.

（2）水素燃焼の作動流体の熱伝導率は燃焼前におい て炭化水素燃焼と比較して特に大きいが，主に冷却損 失が生じる燃焼過程および燃焼終了後においては両者 の熱伝導率の間に極端な差は見られない.
（3）平均ピストン速度を代表速度として円管内乱流 熱伝達式により水素燃焼機関の壁面熱伝達を計算した 場合，燃焼過程での熱伝達量の増加を十分に表すこと ができない.

（4）この原因として，燃焼過程においても変化しな い平均ピストン速度では水素然焼の急激な火炎伝播に 伴う対流の増加が表現できないことが考えられ，燃焼 過程での対流の増加に対応した適切な代表速度の取り 扱いが水素燃焼機関の壁面熱伝達を計算する上での課 題である.

本研究は新エネルギー・産業技術総合開発機構 (NEDO)の産業技術研究助成事業の助成を受けて実施 した研究の一部である.

\section{文献}

（1） 首藤登志夫 - 二口貴之 - 中島泰夫, 水素予混合燃焼機関 の熱効率に関する解析, 機論, 66-644, B (2000), 277-282.

(2) 首藤登志夫 - 鍋谷茂樹 - 中身泰夫, 水素予混合燃焼機関 の等容度および泠却損失の解析, 自技論, 31-4 (2000), 5-10.

(3) 首藤登志夫 - 国永智晴 - 長谷川隆之, 直接噴射層状燃焼 による水素燃焼の泠却損失低減, 機論, 70-691, B (2004), 796-802.

(4) 首藤登志夫・鈴木広行, 水素燃焼機関における壁面熱伝 達式に関する研究, 機論, 68-673, B (2002), 200-206.

(5) 首藤登志夫 - 鈴木広行 - 岡紘子, 水素燃焼機関に適用可 能な新たな壁面熱伝達式, 機論, 69-678, B (2003), 273-279.

(6) 首藤登志夫・鍋谷茂樹・中島泰夫, インジケータ線図を 用いた水素エンジンの燃焼解析に関する研究, 機論, 67654, B (2001), 255-260.

(7) Woschni, G., A Universally Applicable Equation for the Instantaneous Heat Transfer Coefficient in the Internal Combustion Engine, SAE Paper 670931 (1967), 1-13.

（8）日本機械学会編, 流体の熱物性値集, (1983), 丸善.

(9) Kays, W. M., Crawford, M. E., Convective Heat and Mass Transfer, (1980), 243, McGraw-Hill.

(10) 日本機械学会編, 機械工学便覧, (1985), A6-119, 丸善.

（11）首藤登志夫・津賀幸一郎・中島泰夫，メ夕ン直噴層状燃 焼における水素予混合による燃焼促進と椧却損失, 自技 論, 32-1 (2001), 23-28.

(12) 首藤登志夫・津賀幸一郎, メタノールから得られる $\mathrm{H}_{2}$ $\mathrm{CO}-\mathrm{CO}_{2}$ 混合燃料の燃焼および冷却損失特性, 自技論, 324 (2001), 69-74.

(13) 首藤登志夫, 内燃機関における水素の効率的利用に関す る研究, 新エネルギー・産業技術総合開発機構(NEDO)平 成 12 年度産業技術研究助成事業研究成果報告書, 00B65025c (2001), 1-18.

(14) 首藤登志夫, 内燃機関における水素の燃焼, 「天然ガス の高度利用技術」，7章，(2001), 742-750, NTS. 